\title{
Characterizing vertical migration of Microcystis aeruginosa and conditions for algal bloom development based on a light-driven migration model
}

Received: 20 October 2016/ Accepted: 2 September 2017/Published online: 20 September 2017

(C) The Ecological Society of Japan 2017

\begin{abstract}
Light-driven vertical migration is critical in dense aggregation of Microcystis aeruginosa during algal blooms under reduced turbulence conditions in natural water bodies. This study examined the vertical migration characteristics of Microcystis aeruginosa in calm water based on a colony migration model with consideration of cell density change, and demonstrated the effects of mucilage fraction, colony size, irradiance intensity, and water turbidity. The results suggest that colonies with larger radii and under higher irradiance usually had a larger daily averaged retention time at the water surface (DRT). In addition to colony size, mucilage was found to be important in changing the vertical migration behavior of Microcystis colonies, in which increasing mucilage volume fraction can increase the migrating velocity of the colony as well as the length of time it remains at the water surface. Increase of light extinction also favors the aggregation of colonies at the surface. An approximate critical value of $2400 \mu \mathrm{mol}$ photons $\mathrm{m}^{2} \mathrm{~s}^{-1}$ for maximum irradiance was found for persistent algal bloom development under the given simulation conditions. Extremely small colonies exposed to irradiance below the critical value were not likely to migrate to the water surface to form algal blooms. According to the DRT values, three regions with different ranges of irradiance and colony size were proposed as the critical conditions for algal bloom development. Rough comparisons to field observations suggested that these results
\end{abstract}

B. Yao $\cdot$ Y. Gao

Key Laboratory for Mechanics in Fluid Solid Coupling Systems, Institute of Mechanics, Chinese Academy of Sciences, Beijing 100190, China

Q. Liu $(\bowtie)$

Department of Mechanics, School of Aerospace Engineering, Beijing Institute of Technology, Beijing 100081, China

E-mail: liuqq@bit.edu.cn

Z. Cao

State Key Laboratory of Water Resources and Hydropower Engineering Science, Wuhan University, Wuhan 430072, China were reasonable and meaningful, and have the potential to be applied in real cases following further validation by more detailed investigations.

Keywords Vertical migration · Daily-averaged retention time $\cdot$ Colony radius $\cdot$ Irradiance $\cdot$ Mucilage

\section{Introduction}

Algal blooms are caused by dense aggregations of buoyant phytoplankton cells that occasionally accumulate at the water surface and usually form under the vertical migration to the surface of the numerous algal cells that already exist in the water column (Reynolds and Walsby 1975; Kong and Fao 2005; Gao and Liu 2013). In general, algal blooms are thought to occur when the concentration of chlorophyll- $a$ in the water is greater than $10 \mathrm{mg} \mathrm{m}^{-3}$ or the number of algal cells is over 20000 cells $\mathrm{mL}^{-1}$ (Oliver and Ganf 2002). Although the rapid increase of biomass by fast growth of phytoplankton is commonly thought to be essential, algal blooms can appear even when the total number of algal cells is not particularly high. This typically occurs when most of the cells in the water column move upward over a relatively short period of time to form a dense algal layer near the water surface. Compared with the growth of the algae, the vertical migration is a relatively shortterm process that can occur within a couple of hours. Moreover, diurnal changes occur in algal blooms as they usually appear on water surfaces during the night and sink below the surface in strong sunlight during the day (Wallace et al. 2000; Hunter et al. 2008; Chien et al. 2013), making the location of the bloom harder to predict. Therefore, studies on the vertical migration process are important and of wide concern (Hajdu et al. 2007; Bresciani et al. 2014; Wu et al. 2015).

Microcystis aeruginosa is known to often dominate during algal blooms because of its capability to migrate 
within the water column by regulating buoyancy through changing its cell density (Kromkamp and Mur 1984). This vertical migration is driven by diurnal variations of light and is thought to be a critical process for the development of algal blooms (Guven and Howard 2006; Shikata et al. 2015). The daily pattern of vertical migration can be explained by an increase in cell density due to carbohydrate accumulation in the light and a decrease in cell density due to consumption of carbohydrates in the dark (Kromkamp and Mur 1984; Visser et al. 1997; Chien et al. 2013). Some mathematical models have been established to describe this process based on laboratory experiments (Okada and Aiba 1986; Kromkamp and Walsby 1990; Visser et al. 1997).

Colony formation is another important feature of Microcystis, which is also a potential mechanism of algal blooms. In natural waters, especially when algal blooms occur, many Microcystis cells aggregate together to form large colonies. Naselli-Flores and Barone (2003) observed that colony diameters were relatively larger (1-4 mm) during the bloom than at other times of the year (less than $1 \mathrm{~mm}$ ). Observations from several Spanish lakes and reservoirs showed similar results (Costas et al. 2008). Compared with individual cells, colony formation not only has the advantage of counteracting grazing because of the size and mechanical toughness of the envelope (Yang et al. 2006), but also affects the vertical distribution of Microcystis in natural waters. Both simulation results and observations from previous reports (Rabouille et al. 2003; Wu and Kong 2009; Chien et al. 2013; Yu et al. 2015) suggest that large colonies are more readily able to overcome the entraining forces of turbulence to gain access to the surface region and concentrate in the surface layers, whereas small colonies were more easily entrained and prone to uniform distribution in the water column.

However, the majority of previous studies have focused on the effect of colony radius on its vertical migration, and further examination of the influence of irradiance is still needed, as the light regime is the major driving force in vertical migration and plays an important role in the development of algal blooms. Moreover, the critical irradiance conditions for algal bloom development have not been fully discussed before. Therefore, the main purpose of this study was to focus on the vertical migration characteristics of Microcystis and the critical irradiance conditions for bloom formation. First, a light-driven vertical migration model was used to study the migration characteristics of Microcystis colonies in still water, and the influences of mucilage proportion, colony radius, water turbidity, and light intensity were analyzed according to the simulation results. The dailyaveraged retention time (DRT) of Microcystis colonies staying at the water surface was then proposed and calculated. Finally, the combined effects of the colony radius and irradiance were discussed and an approximation of the critical conditions for algal bloom development were suggested according to the simulation results.

\section{Materials and methods}

The light-driven migration model for Microcystis was mainly based on those of Kromkamp and Walsby (1990) and Visser et al. (1997), for which the main equations are described as follows.

\section{Light-induced density change for colonies}

Colonies consist of multiple single cells bonded together by mucilage, and the density of a colony can then be described as:

$\rho_{\text {colony }} V_{\text {colony }}=\rho_{\text {cell }} V_{\text {cell }}+\rho_{\text {mucilage }} V_{\text {mucilage }}$,

where $\rho_{\text {colony }}, \rho_{\text {cell }}$, and $\rho_{\text {mucilage }}$ are densities of the colony, cells, and mucilage, respectively $\left(\mathrm{kg} \mathrm{m}^{-3}\right)$; and $V_{\text {colony }}, V_{\text {cell }}$, and $V_{\text {mucilage }}$ are volumes of the colony, cells, and mucilage, respectively $\left(\mathrm{m}^{3}\right)$.

The density of mucilage could be calculated according to Reynolds et al. (1981) as:

$\rho_{\text {mucilage }}=\rho_{\text {water }}+0.7$,

where $\rho_{\text {water }}$ is the density of water $\left(\mathrm{kg} \mathrm{m}^{-3}\right)$.

Assuming that the volume fraction of cells in an algal colony is $n_{\text {cell }}$, the density of the colony becomes:

$\rho_{\text {colony }}=\rho_{\text {cell }} n_{\text {cell }}+\rho_{\text {mucilage }}\left(1-n_{\text {cell }}\right)$.

The mechanism of colony formation is highly complex, and its composition and dynamics remain unclear. In addition, the volume ratios of mucilage vary among different colonies in the real case. For simplicity, it was assumed that the density of mucilage ( $\left.\rho_{\text {mucilage }}\right)$ and the volume fraction of algal cells $\left(n_{\text {cell }}\right)$ in the colony are both constant. Thus, the rate of change for the density of the algal colony only depends on the rate of change of the algal cells, i.e.:

$\frac{d \rho_{\text {colony }}}{d t}=n_{\text {cell }} \frac{d \rho_{\text {cell }}}{d t}$.

The density change rate of algal cells can be described by a function by Visser et al. (1997) based on laboratory observations, in which density increases as irradiance increases until it reaches a maximum value at $278 \mu \mathrm{mol}$ photons $\mathrm{m}^{-2} \mathrm{~s}^{-1}$, and then decreases abruptly to reach negative values (photo-inhibition) when photon irradiance exceeds $1347 \mu \mathrm{mol}$ photons $\mathrm{m}^{-2} \mathrm{~s}^{-1}$. These changes occur under light conditions and the rate of change of cell density caused by the accumulation of carbohydrate is given by Visser et al. (1997):

$\frac{d \rho_{\text {cell }}}{d t}=\left(N_{0} / 60\right) I e^{\left(-I / I_{0}\right)}+N_{1}$,

where $\mathrm{d} \rho_{\text {cell }} / \mathrm{dt}$ is the rate of change of cell density $(\mathrm{kg}$ $\mathrm{m}^{-3} \mathrm{~min}^{-1}$ ) at photon irradiance $I, I$ is the photon irradiance $\left(\mu \mathrm{mol}\right.$ photons $\left.\mathrm{m}^{-2} \mathrm{~s}^{-1}\right), I_{0}$ is $I$ where $\mathrm{d} \rho_{\text {cell }} / \mathrm{dt}$ 
Table 1 Values for the constants of the vertical migration model

\begin{tabular}{|c|c|c|c|}
\hline Parameters & Descriptions & Values & References \\
\hline $\begin{array}{l}\rho_{\text {water }} \\
\xi \\
\xi \\
\rho_{\text {mucilage }} \\
n_{\text {cell }} \\
\Phi \\
N_{0} \\
I_{0} \\
I_{m} \\
N_{1} \\
f_{1} \\
f_{2} \\
\rho_{\text {min }} \\
\rho_{\text {max }}\end{array}$ & $\begin{array}{l}\text { Density of water } /\left(\mathrm{kg} \mathrm{m}^{-3}\right) \\
\text { Viscosity of water } /\left(\mathrm{kg} \mathrm{m}^{-1} \mathrm{~s}^{-1}\right) \\
\text { Extinction coefficient } /\left(\mathrm{m}^{-1}\right) \\
\text { Density of mucilage } /\left(\mathrm{kg} \mathrm{m}^{-3}\right) \\
\text { Cell content in colony } /(\%) \\
\text { Coefficient of form resistance } \\
\left.\text { A normative factor } /\left(\mathrm{kg} \mathrm{m}^{-3} \mu \mathrm{mol}^{-1} \text { photons m}\right)^{2}\right) \\
\text { Irradiance where } \rho(I) \text { is maximum } /\left(\mu \mathrm{mol} \text { photons } \mathrm{m}^{2} \mathrm{~s}^{-1)}\right. \\
\text { Maximum irradiance at the water surface } /\left(\mu \mathrm{mol} \mathrm{photons} \mathrm{m}^{2} \mathrm{~s}^{-1)}\right. \\
\text { Rate of density change at } I=0 /\left(\mathrm{kg} \mathrm{m}^{-3} \mathrm{~min}^{-1}\right) \\
\text { Density slope in dark } /\left(\mathrm{min}^{-1}\right) \\
\text { Rate of density change without carbohydrate storage } /\left(\mathrm{kg} \mathrm{m}^{-3} \mathrm{~min}^{-1}\right) \\
\text { Minimum of colony density } /\left(\mathrm{kg} \mathrm{m}^{-3}\right) \\
\text { Maximum of colony density } /\left(\mathrm{kg} \mathrm{m}^{-3}\right)\end{array}$ & $\begin{array}{l}998 \\
10^{-3} \\
2.0 \\
998+0.7 \\
80 \\
1.0 \\
0.0945 \\
277.5 \\
1000 \\
-0.0165 \\
-9.49 \times 10^{-4} \\
-0.984 \\
920 \\
1085\end{array}$ & $\begin{array}{l}\text { Reynolds et al. (1981) } \\
\text { Reynolds et al. (1981) } \\
\text { Visser et al. (1997) } \\
\text { Visser et al. (1997) } \\
\text { Visser et al. (1997) } \\
\text { Visser et al. (1997) } \\
\text { Visser et al. (1997) } \\
\text { Visser et al. (1997) } \\
\text { Reynolds et al. (1981) } \\
\text { Reynolds et al. (1981) }\end{array}$ \\
\hline
\end{tabular}

reaches its maximum value ( $\mu \mathrm{mol}$ photons $\mathrm{m}^{-2} \mathrm{~s}^{-1}$ ), $N_{0}$ is a normative factor $\left(\mathrm{kg} \mathrm{m}^{-3} \mu \mathrm{mol}^{-1}\right.$ photons $\left.\mathrm{m}^{2}\right)$, and $N_{1}$ is the rate of density change at $I=0\left(\mathrm{~kg} \mathrm{~m}^{-3}\right.$ $\min ^{-1}$ ).

A positive linear correlation was found between cell density and the rates of density decrease under dark conditions. This decrease is mainly due to respiration and the rate of change depends on the actual cell density (Visser et al. 1997):

$\frac{d \rho_{c e l l}}{d t}=f_{1} \times \rho_{i}+f_{2}$

where $\mathrm{d} \rho_{\text {cell }} / \mathrm{dt}$ is the rate of density change in the dark $\left(\mathrm{kg} \mathrm{m}^{-3} \mathrm{~min}^{-1}\right), \rho_{\mathrm{i}}$ is the initial density $\left(\mathrm{kg} \mathrm{m}^{-3}\right), f_{1}$ is the slope of the density curve $\left(\mathrm{min}^{-1}\right)$, and $f_{2}$ is the theoretical rate of density change with no carbohydrate storage in the cells $\left(\mathrm{kg} \mathrm{m}^{-3} \mathrm{~min}^{-1}\right)$. The threshold between the light and dark regime was set to $10.9 \mu \mathrm{mol}$ photons $\mathrm{m}^{-2} \mathrm{~s}^{-1}$, corresponding to the intersection of the irradiance-response curve with the $x$-axis at low values of photon irradiance (Visser et al. 1997).

The value of photon irradiance at the depth of the cyanobacterial colony $(z)$ can be described according to the Lambert-Beer law of exponential light extinction:

$I_{z}=I_{s} e^{-\xi z}$,

where $\xi$ is the extinction coefficient of the water $\left(\mathrm{m}^{-1}\right), z$ is the depth of the colony $(\mathrm{m})$, and $I_{\mathrm{S}}$ is the irradiance at the water surface during the photoperiod, which is described by a sine function with a maximum value of photon irradiance at noon $\left(I_{\mathrm{m}}\right)$ and the length of the photoperiod $\left(D_{L}\right)$ (Aksnes and Egge 1991):

$I_{s}=I_{m} \sin \left(\pi t / D_{L}\right)$.

The self-shading effect (i.e., light extinction by colonies in the upper layer) is not considered in the above equations since the simulations carried out in this study were based on a single colony, but it can be described if absolute colony concentrations are known. Instead, different values of extinction coefficient (water turbidity) are used for simplicity when discussing the self-shading effect on the formation of algal blooms in later sections.

The rising/sinking velocity of colonies in still water

The rising/sinking velocity of a colony was estimated by the Stokes' law for a sufficiently small and solid spherical particle in still water:

$v=\frac{d z}{d t}=\frac{2 g r^{2}\left(\rho_{\text {colony }}-\rho_{\text {water }}\right)}{9 \phi \mu}$,

where $r$ is the equivalent colony diameter (represented as a sphere, $\mathrm{m}), \mathrm{g}$ is the gravitational acceleration $(9.8 \mathrm{~m}$ $\mathrm{s}^{-2}$ ), $\Phi$ is a form resistance coefficient, and $\mu$ is the viscosity of water $\left(10^{-3} \mathrm{~kg} \mathrm{~m}^{-1} \mathrm{~s}^{-1}\right)$. For a buoyant colony $\rho_{\text {colony }}<\rho_{\text {water }}$, the velocity $(v)$ has a negative value, indicating that the colony will move upwards.

The above equations were integrated and implemented by a computer program written in MATLAB ${ }^{\circledR}$ 2013a. The values of model constants are presented in Table 1.

The daily-averaged retention time for a colony at the water surface (DRT), was used to discuss the critical conditions for the bloom formation, which is defined as the average time period during which the colony remains at the water surface within a day. It was calculated based on the simulation results of the vertical migration curve.

\section{Results}

Simulations of vertical movement

The simulation began with a colony with a density of $980 \mathrm{~kg} \mathrm{~m}^{-3}$ located at the water surface at dawn (i.e., it was buoyant after spending the night in the dark). The simulated density change and vertical movement within a period of $48 \mathrm{~h}$ for a colony with a $200 \mu \mathrm{m}$ radius are shown in Fig. 1. The density increased owing to the accumulation of carbohydrate in the light and decreased 


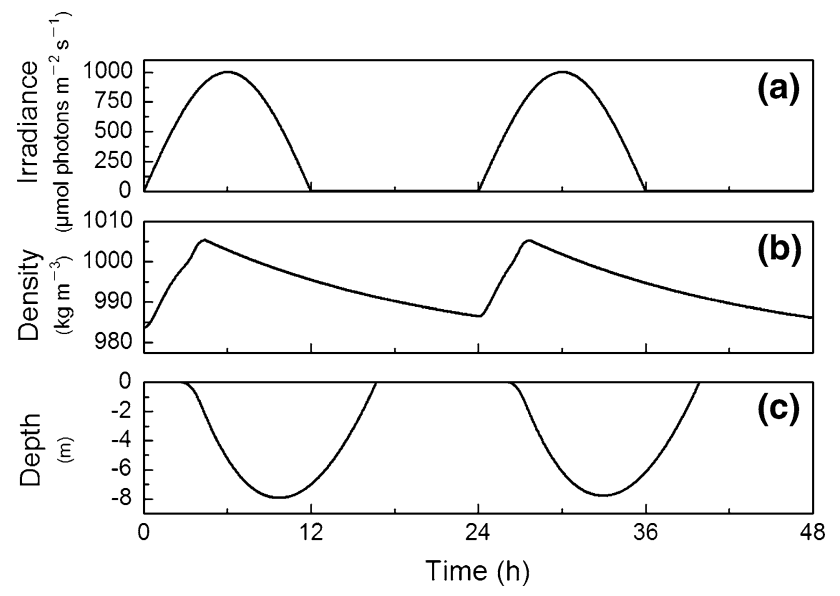

Fig. 1 Simulated density changes (b) and vertical movements (c) of a $200-\mu \mathrm{m}$ radius colony under the given irradiance with maximum irradiance of $1000 \mu \mathrm{mol}$ photons $\mathrm{m}^{2} \mathrm{~s}^{-1}$ (a)

as a result of the consumption of carbohydrate in the dark (Fig. 1). The colony remained at the water surface until its density exceeded that of the water. It then began to sink, reached a certain depth, and floated up again after regaining buoyancy. This phenomenon is the diurnal migration found in natural waters, where $\mathrm{Mi}$ crocystis colonies usually float at the water surface in the early morning, and disappear from the water surface after a few hours of exposure to irradiance, oscillating periodically between the surface and a specific depth in the water column in accordance with the variations of solar irradiation.

Factors influencing the vertical migration

\section{Mucilage}

Different mucilage volume proportions were considered for a $200-\mu \mathrm{m}$ radius colony (Fig. 2a). The increase of mucilage substantially increased the oscillating period of the colony in the water column and reduced the time that it stayed at the water surface. Its DRT values decreased from about 11.6 to $4.3 \mathrm{~h}$ when $n_{\text {cell }}$ values decreased from 1.0 to 0.4 and the maximum migrating depth changed slightly (Fig. 2a). In addition, the effect of mucilage volume fraction was radius sensitive (Fig. 2b), in which smaller colonies were more influenced. For instance, when $n_{\text {cell }}$ values increased from 0.6 to 0.8 , the DRT values increased from about 3.0 to $5.8 \mathrm{~h}$ for a $150-\mu \mathrm{m}$ radius colony and from 11.6 to $13.1 \mathrm{~h}$ for a $500-\mu \mathrm{m}$ radius colony, increasing by 93 and $13 \%$, respectively.

\section{Colony size}

The effect of a colony's size on its vertical movement was simulated and it was found that larger colonies could

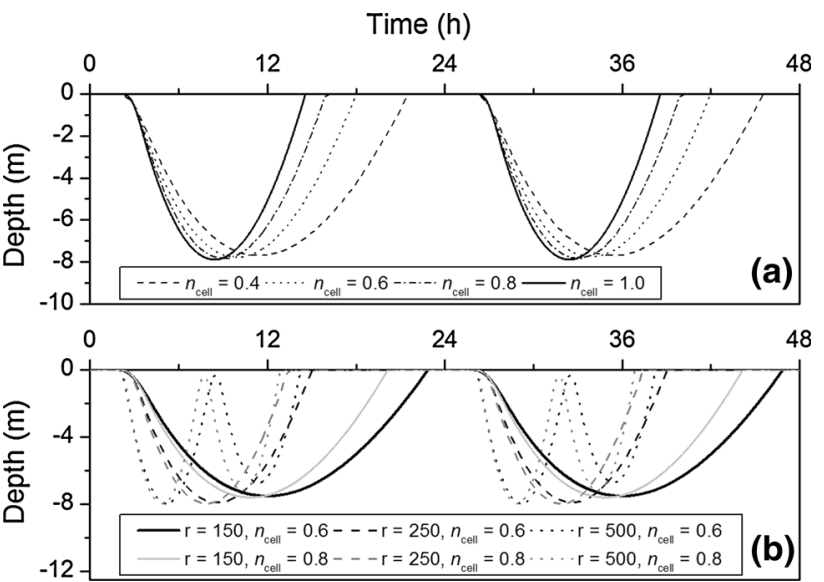

Fig. 2 Effect of mucilage proportion $(1-$ the volume fraction of algal cells, $\left.n_{\text {cell }}\right)$ on the vertical movement of Microcystis colonies under maximum irradiance of $1000 \mu \mathrm{mol}$ photons $\mathrm{m}^{2} \mathrm{~s}^{-1}$ for a a $200-\mu \mathrm{m}$ radius colony, and $\mathbf{b}$ colonies with different radii

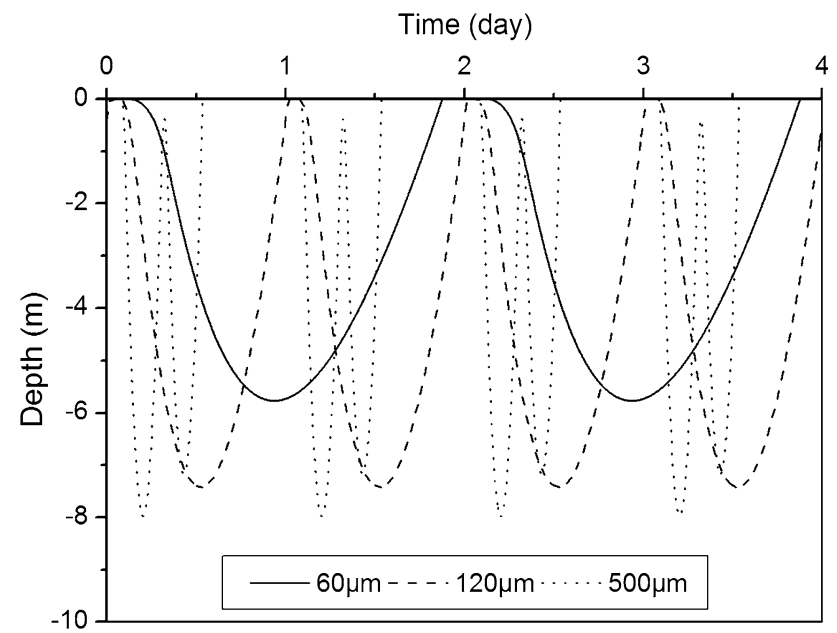

Fig. 3 Vertical migration of Microcystis colonies with different radii $(r)$ under maximum irradiance of $1000 \mu \mathrm{mol}$ photons $\mathrm{m}^{2} \mathrm{~s}^{-1}$

migrate to greater depths than smaller colonies (Fig. 3). Moreover, larger colonies also had greater migration speeds and a higher oscillating frequency; colonies with radius larger than $500 \mu \mathrm{m}$ could oscillate several times within a day, whereas colonies with radius less than $60 \mu \mathrm{m}$ only migrated beneath the water surface under the given light conditions during the whole day, indicating that they would not be prone to migrate to the water surface to form algal blooms. The DRT values also increased with colony radius, suggesting that larger colonies more easily aggregate at the water surface.

\section{Water turbidity}

The effect of water turbidity was simulated by changing the value of light extinction coefficient (Fig. 4). Increasing water turbidity could lead to smaller migration depth and larger DRT value; the colonies could 


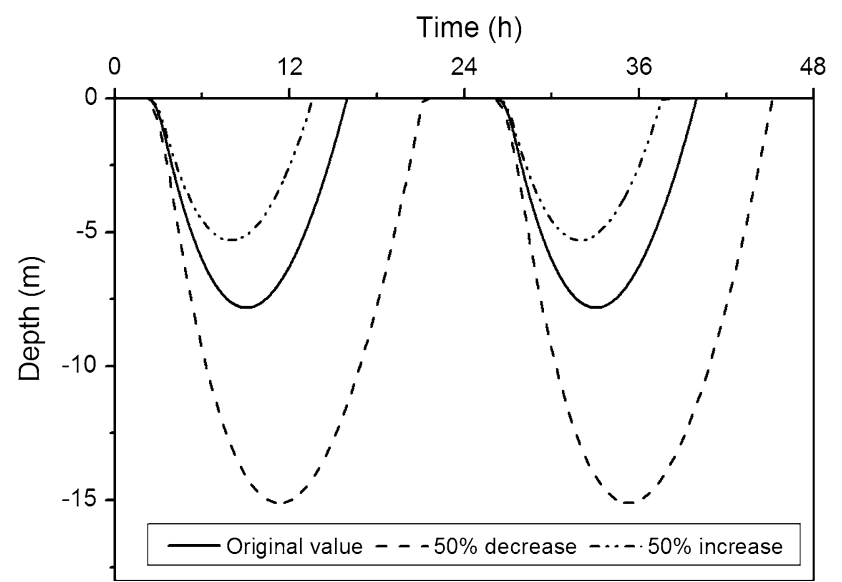

Fig. 4 Effect of water turbidity (light extinction coefficient) on the vertical migration of a $200-\mu \mathrm{m}$ radius colony under maximum irradiance of $1000 \mu \mathrm{mol}$ photons $\mathrm{m}^{2} \mathrm{~s}^{-1}$

therefore migrate much deeper when the extinction coefficient of light in the water decreased and they were more likely to stay in the upper waters when the extinction coefficient increased. For a $200-\mu \mathrm{m}$ radius colony, the maximum migration depth reduced from 8 to $5 \mathrm{~m}$ when the light extinction coefficient increased by $50 \%$ and its DRT value increased from about 10 to $12 \mathrm{~h}$. In contrast, if the light extinction coefficient decreased by $50 \%$, its maximum migration depth increased to about $15 \mathrm{~m}$ and its DRT value reduced to about $5 \mathrm{~h}$ (Fig. 4).

\section{Irradiance}

The density changes of a $200-\mu \mathrm{m}$ radius colony under six different irradiance conditions were simulated, in which the maximum irradiances $\left(I_{\mathrm{m}}\right)$ were set to 500,1000 , $1500,2000,2500$, and $3000 \mu \mathrm{mol}$ photons $\mathrm{m}^{2} \mathrm{~s}^{-1}$ (Fig. 5). The results showed that when $I_{\mathrm{m}}$ was less than or equal to $2000 \mu \mathrm{mol}$ photons $\mathrm{m}^{2} \mathrm{~s}^{-1}$, the density of the

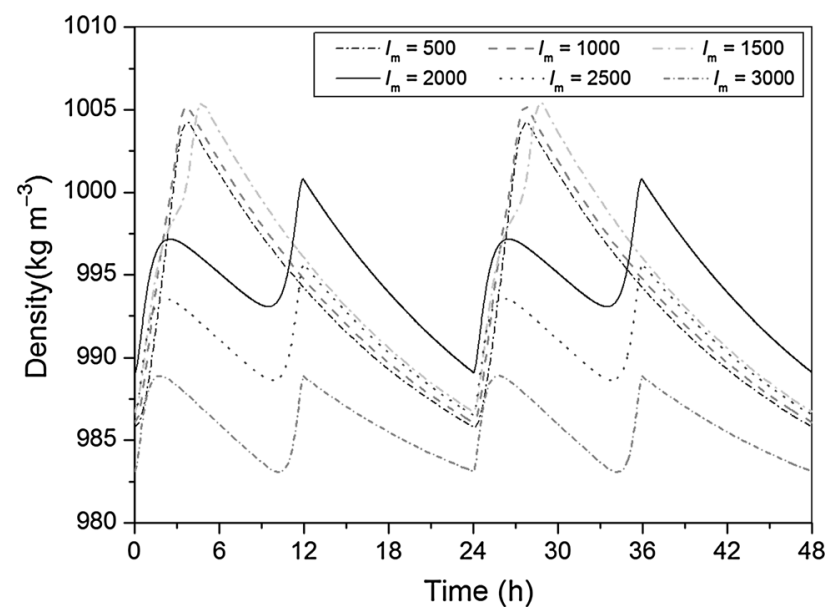

Fig. 5 Density changes of a $200-\mu \mathrm{m}$ radius colony under different maximum irradiance $\left(I_{\mathrm{m}}\right)$ colony fluctuated around the density of water, which could lead to periodic sinking or floating movements of the colony in the water column. However, when $I_{\mathrm{m}}$ was greater than or equal to $2500 \mu \mathrm{mol}$ photons $\mathrm{m}^{2} \mathrm{~s}^{-1}$, the density of the colony was always smaller than that of the water, suggesting that the colony would continue floating after it reached the water surface. This indicates that there may be a critical value for irradiance (e.g., probably around $2500 \mu \mathrm{mol}$ photons $\mathrm{m}^{2} \mathrm{~s}^{-1}$ for a $200-\mu \mathrm{m}$ radius colony according to the model results shown in Fig. 5) and when the maximum value of light intensity exceeds it, the colonies will remain at the water surface for the whole day as a result of strong photo-inhibition.

\section{Critical conditions for development of algal blooms}

The changes of DRT vs. $I_{\mathrm{m}}$ for a $200-\mu \mathrm{m}$ radius colony (Fig. 6) indicate that the DRT value first reduced within the ranges of $I_{\mathrm{m}}$ from $0 \mu \mathrm{mol}$ photons $\mathrm{m}^{2} \mathrm{~s}^{-1}$ to about $1500 \mu \mathrm{mol}$ photons $\mathrm{m}^{2} \mathrm{~s}^{-1}$ because increased $I_{\mathrm{m}}$ within this range increased the migration depth, reducing the length of time for which the colony remained at the water surface (the migration speed was largely dependent on radius). It then increased to reach its maximum value of $24 \mathrm{~h}$ at about $2400 \mu \mathrm{mol}$ photons $\mathrm{m}^{2} \mathrm{~s}^{-1}$ as the result of decreasing migration depth (especially after about $2100 \mu \mathrm{mol}$ photons $\mathrm{m}^{2} \mathrm{~s}^{-1}$ ). It subsequently remained unchanged, which is very interesting and suggests that the critical value of $I_{\mathrm{m}}$ for a $200-\mu \mathrm{m}$ radius colony is about $2400 \mu \mathrm{mol}$ photons $\mathrm{m}^{2} \mathrm{~s}^{-1}$. When this critical value is exceeded, the colony may remain at the water surface for the whole day.

The relationship of DRT vs. colony radius (Fig. 7) shows that the DRT value remained about zero until the colony radius exceeded about $50 \mu \mathrm{m}$, after which the colony migrated under the water surface. It reached a peak value of about $7 \mathrm{~h}$ at $75 \mu \mathrm{m}$ (the migration period was about 2 days) within the radius range of $50-85 \mu \mathrm{m}$. In the range from about 85 to $120 \mu \mathrm{m}$, the DRT value decreased to zero (the migration period increased to about 1 day). It then rapidly increased to $14.4 \mathrm{~h}$ at about

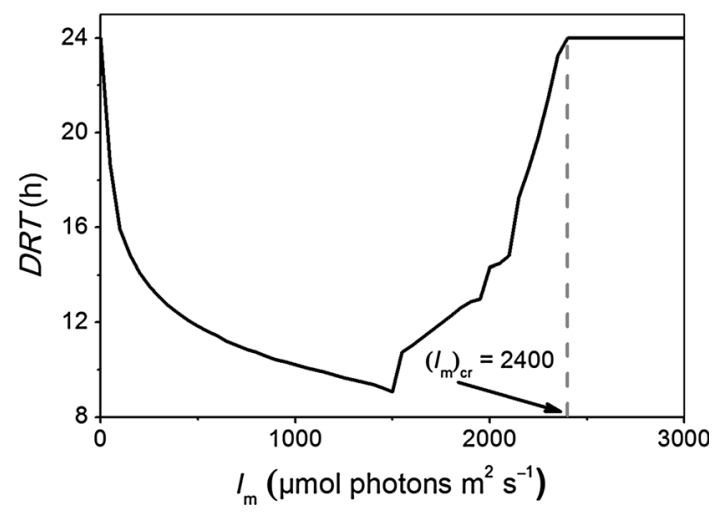

Fig. 6 Daily averaged retention time (DRT) vs. maximum irradiance $\left(I_{\mathrm{m}}\right)$ for a $200-\mu \mathrm{m}$ radius colony 


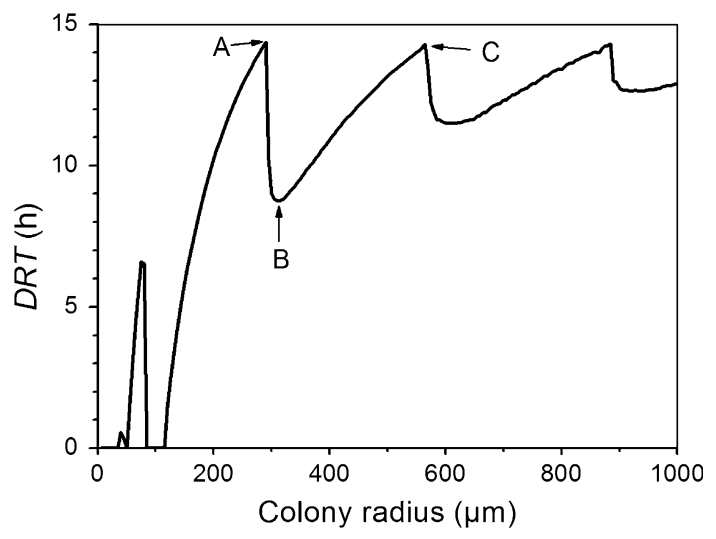

Fig. 7 Daily averaged retention time (DRT) vs. colony radius under maximum irradiance of $1000 \mu \mathrm{mol}$ photons $\mathrm{m}^{2} \mathrm{~s}^{-1}$, where A, B, and C denote DRT values for colonies with radius of 290,310 , and $560 \mu \mathrm{m}$, respectively

$290 \mu \mathrm{m}$, after which the DRT value fluctuated around $13 \mathrm{~h}$. The "jagged" shape was mainly due to the migration patterns of colonies with different radii, in which increase of colony radius resulted in an increase of both migration speed and frequency. Taking three different sized colonies (A, B, and C in Fig. 7, with radii of 290,310 , and $560 \mu \mathrm{m}$, respectively) for example, Colony A only migrated once within a day with a DRT value of $14.4 \mathrm{~h}$. Colony B migrated twice within a day, but its migration speed was only a little larger than that of Colony A; therefore, the length of time during which it remained below the water surface was higher than that of Colony A and its DRT value decreased to $8.7 \mathrm{~h}$. For Colony $\mathrm{C}$, although it also migrated twice within a day, its migration speed was much larger than that of Colony $\mathrm{B}$; therefore, its DRT value increased to $14.3 \mathrm{~h}$. Comparing Colonies $\mathrm{A}$ and $\mathrm{C}$, the time taken for Colony $\mathrm{C}$ to migrate twice was nearly the same as the time taken for Colony A to migrate once, leading to similar DRT values for the two colonies.

Complex variations of DRT vs. colony radius and $I_{\mathrm{m}}$ were found (Fig. 8) as a result of the combined nonlinear relationships of DRT with both $I_{\mathrm{m}}$ (Fig. 6) and colony radius (Fig. 7). However, generally larger colony radii and $I_{\mathrm{m}}$ also led to larger DRT values, suggesting that larger colonies under stronger irradiation are more prone to remain at the water surface and cause algal blooms. The mapped area could be roughly divided into three regions according to different DRT ranges, which were named Region $\mathrm{A}, \mathrm{B}$, and $\mathrm{C}$ as follows:

Region A: colony radius $<140 \mu \mathrm{m}$, and $100 \mu \mathrm{mol}$ photons $\mathrm{m}^{2} \mathrm{~s}^{-1}<I_{\mathrm{m}}<2400 \mu \mathrm{mol}$ photons $\mathrm{m}^{2} \mathrm{~s}^{-1}$. Algal blooms seemed unlikely to form in this region as the DRT values were relatively small (generally the DRT values were close to zero).

Region B: $I_{\mathrm{m}}<100 \mu \mathrm{mol}$ photons $\mathrm{m}^{2} \mathrm{~s}^{-1}$ (B1) or $I_{\mathrm{m}}>2400 \mu \mathrm{mol}$ photons $\mathrm{m}^{2} \mathrm{~s}^{-1}$ (B2). In this area, persistent algal blooms are likely to occur if there are sufficient colonies present in the water column, as the
DRT values are $24 \mathrm{~h}$, indicating that the colonies will stay at the water surface for the whole day.

Region C: colony radius $>140 \mu \mathrm{m}$, and $100 \mu \mathrm{mol}$ photons $\mathrm{m}^{2} \mathrm{~s}^{-1}<I_{\mathrm{m}}<2400 \mu \mathrm{mol}$ photons $\mathrm{m}^{2} \mathrm{~s}^{-1}$, including C1 (DRT ranges of 8-16 h) and C2 (DRT ranges of about 16-24 h). In this area, the DRT values generally increased with the increase of colony radius and $I_{\mathrm{m}}$, and the diurnal migration may lead to periodic algal blooms in the water body if sufficient colonies are present.

\section{Discussion}

The migration model in this study was according to Visser et al. (1997), in which the calculated density change rate of Microcystis cells was found to be in good agreement with the experimental data, and the estimated maximum migration depth was thought to be roughly in accordance with the observed vertical chlorophyll profile from Lake Nieuwe Meer, the Netherlands (Visser et al. 1996). The model of Visser et al. (1997) was also integrated into a one-dimensional particle trajectory model by Chien et al. (2013) to simulate the diurnal vertical migration patterns of different-sized Microcystis colonies in Hsin-shan Reservoir, Taiwan, and the simulated diurnally varying population profile coincided with the field data when the radii of the multi-sized colonies were in a beta distribution. Another similar study also showed a good agreement with the field data acquired in Lake Vinkeveen, the Netherlands (Yu et al. 2015). The density change functions as well as its parameter values used in these studies were almost identical to those of Visser et al. (1997), suggesting that the model had the capability to produce a good simulation to the diurnal migration of Microcystis in natural water bodies.

A rough comparison was also carried out between the simulation results of this study and the observations by $\mathrm{Wu}$ and Kong (2009), in which they reported that $\mathrm{Mi}$ crocystis colonies with radii larger than $120 \mu \mathrm{m}$ were mainly concentrated in the surface layers (at 0 and $0.5 \mathrm{~m}$ ) under both calm and windy conditions as well as under different light intensities (the $I_{\mathrm{m}}$ during the observations was $2123 \mu \mathrm{mol}$ photons $\mathrm{m}^{2} \mathrm{~s}^{-1}$ ), showing little response to the diurnal changes of solar irradiation. It is interesting to note that these colony radii and $I_{\mathrm{m}}$ values are close to the critical values given by the present study (Fig. 7), which are about $140 \mu \mathrm{m}$ and $2400 \mu \mathrm{mol}$ photons $\mathrm{m}^{2} \mathrm{~s}^{-1}$, respectively. This may be explained by the results shown in Fig. 7, in which the calculated DRT values of colonies with these radii and irradiance levels tend to be more than about $16 \mathrm{~h}$ (i.e., they will remain at the water surface most of the day). As a result, no obvious diurnal migrations were found for these colonies at the observing time (between 7:00 and 19:00). In contrast, the DRT values for the colonies $<36 \mu \mathrm{m}$ under such irradiance conditions were less than $10 \mathrm{~h}$, which is also in accordance with previous observations 


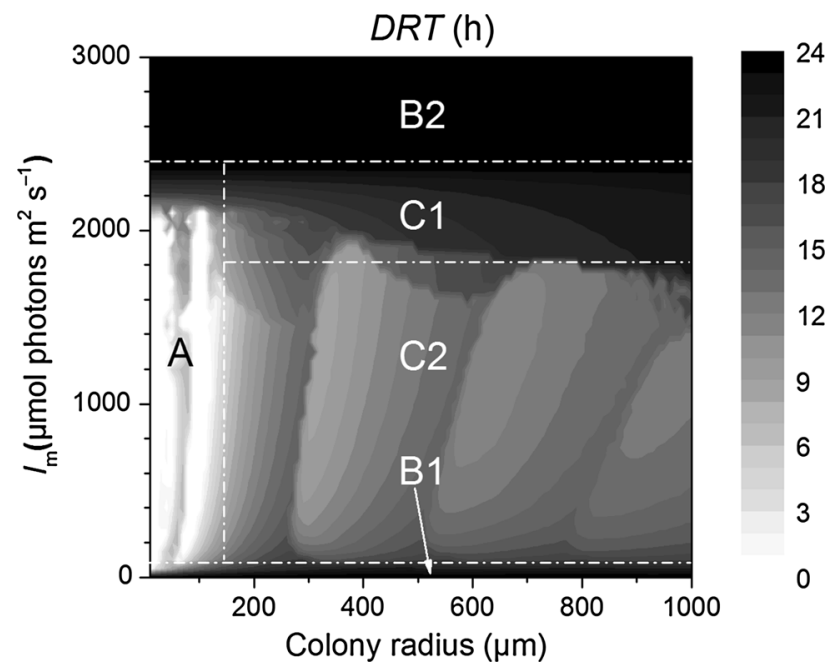

Fig. 8 A map of daily averaged retention time (DRT) vs. colony radius and maximum irradiance $\left(I_{\mathrm{m}}\right)$, in which three different areas are categorized according to DRT values: A, surface aggregation is unlikely to occur; B1 and B2, persistent aggregation at the water surface is likely to occur; and $\mathrm{C} 1$ and $\mathrm{C} 2$, periodic surface aggregation could take place, especially in $\mathrm{C} 2$

for the middle layers of the water column when the wind speeds were low (Wu and Kong 2009).

Both weak $\left(I_{\mathrm{m}}<100 \mu \mathrm{mol}\right.$ photons $\left.\mathrm{m}^{2} \mathrm{~s}^{-1}\right)$ and strong $\left(I_{\mathrm{m}}>2400 \mu \mathrm{mol}\right.$ photons $\left.\mathrm{m}^{2} \mathrm{~s}^{-1}\right)$ light intensity can induce colonies to stay at the water surface throughout the day, due to low cell density caused by a severe lack of photo-irradiance or strong photo-inhibition (Fig. 8). However, it should also be noted that exposure to excess light could severely reduce the photosynthetic quantum efficiency of the Microcystis cells and induce large colonies to change into smaller colonies or single cells ( $\mathrm{Wu}$ and Kong 2010). According to the observations in Lake Taihu, China ( $\mathrm{Wu}$ and Kong 2010), after 4-h exposure to direct solar radiation (the $I_{\mathrm{m}}$ was 2349 ), about $60 \%$ of the colonies larger than $36 \mu \mathrm{m}$ changed into smaller colonies and single cells. A reduction of $30 \%$ of the light at the water surface could substantially reduce that ratio to only about $10 \%$. The changes in diameter may have the advantage of avoiding excess irradiation for large colonies, as smaller colonies are likely to be distributed in the deeper water layer. However, the mechanism for these changes remains unclear, and it is not considered in the present model.

Mucilage is important for Microcystis colonies, and it has multiple functions such as nutrient storage, protection against grazing and digesting, and density deduction (Reynolds 2007). The mean density of the mucilage in living Microcystis colonies was determined to be typically $100.07 \%$ of the density of the water in which they are suspended (Reynolds et al. 1981) and was considered to have effects on the vertical sinking velocities (Reynolds 2007). For colonies with the same radius, the increase of mucilage proportion could reduce the floating/sinking velocities of the colony as well as the time period for which it remains at the water surface according to the modeling results (see Fig. 2a). When the density of cells in the colony is increasing and becoming larger than the water density, mucilage has the potential to reduce the sinking speed of the colony. In contrast, when cell density is reducing and becoming smaller than the water density, mucilage also has the potential to reduce its floating velocity. However, it should be noted that this does not mean that the existence of mucilage must reduce the migrating velocity, as colony radius also increases for colonies with the same number of cells, and the migration velocity is determined by the product of the square of the radius $\left(r^{2}\right)$ and the density difference $\left(\rho_{\text {colony }}-\rho_{\text {water }}\right)$ according to the Stokes law (see Eq. 9). The benefit of mucilage investment in terms of reduced density difference can be described as follows (Hutchinson 1967):

$\left(\rho_{\text {colony }}-\rho_{\text {mucilage }}\right) /\left(\rho_{\text {mucilage }}-\rho_{\text {water }}\right)>a(a+1)$,

where $a$ is the factor by which the mucilage increases the unit diameter, and it was argued that $a$ must be $<4.3$ if it were to depress the settling velocities of the same volume of individual Microcystis cells (Walsby and Reynolds 1980).

The mechanism of colony formation for Microcystis currently remains unclear as it is very complicated and affected by multiple factors such as nutrient enrichment and predation (Wang et al. 2010). Since the compositions and proportions of mucilage vary from colony to colony, and little knowledge is available at present, a constant volume fraction of 0.2 (determined by rough estimations from some available microphotographs of Microcystis colonies) was used in this study. The consideration of mucilage on the vertical migration of $\mathrm{Mi}$ crocystis is necessary according to the modeling results. Future studies are needed to further quantify this effect to make the model more precise and applicable.

Water turbidity is another important factor that affects the vertical migration of Microcystis as it determines the irradiance that can be obtained by the colonies as well as their vertical distributions in the water column (Shigesada and Okubo 1981). In natural water bodies such as lakes, water turbidity is mainly influenced by scattering by suspended particles and absorption by phytoplankton (Liu et al. 2012). As scattering only changes the direction of light propagation, the attenuation of light underwater is primarily due to absorption by phytoplankton (Scheffer et al. 1997), among which the self-shading effect is an important part, especially during the period of algal blooms in which a large number of colonies migrate to the water surface. Colonies near the water surface can absorb part of the light that penetrates into the deep water and reduce the light intensity in the water column. As a result, the irradiance that can be obtained in the water column is reduced, which will change both the migration depth and period for the colonies, consequently accelerating the aggregation of colonies near the water surface according to the simulation results (Fig. 3), supporting favorable condi- 
tions for algal bloom development. In addition, the change of light extinction coefficient is dynamic, increasing with the number of colonies floating and reducing with the number of colonies sinking in the water column (Shigesada and Okubo 1981). This may have a notable impact on the critical irradiance for algal bloom development in real water bodies. Therefore, the use of a constant light extinction coefficient to simulate the migration process in the real water body may not be appropriate, and the relationship between the coefficient and number of colonies needs to be established based on further observations.

\section{Conclusions}

This study examined the characteristics of vertical movements of Microcystis in calm water based on a colony migration model with the consideration of changes to cell density, carrying out analyses of the effects of mucilage proportion, colony radius, $I_{\mathrm{m}}$, and the light extinction coefficient of water on the vertical migration of Microcystis colonies, and demonstrated the effects of colony size and irradiation intensity on the DRT of algal blooms.

The results suggest that larger radius and higher irradiance generally leads to larger DRT values, and an approximate critical value of $2400 \mu \mathrm{mol}$ photons $\mathrm{m}^{2} \mathrm{~s}^{-1}$ for $I_{\mathrm{m}}$ was found for persistent aggregation of Microcystis colonies under the given simulation conditions. Extremely small colonies (e.g., colony radius $<30 \mu \mathrm{m}$ ) exposed to light below the critical irradiance (e.g., $I_{\mathrm{m}}=1000 \mu \mathrm{mol}$ photons $\mathrm{m}^{2} \mathrm{~s}^{-1}$ ) were unlikely to migrate to the water surface to form algal blooms. According to DRT values, three regions with different ranges of irradiance and colony size were proposed as rough critical conditions for algal blooms development. In addition, mucilage was found to be important in changing the vertical migration behavior of Microcystis colonies; increasing the volume fraction of mucilage can reduce both the floating/sinking velocities of the colony and the time period that it remains at the water surface. Increasing water turbidity also favors the aggregation of colonies at the surface.

Although the model ran under the given assumed scenarios such as colony radius and $I_{\mathrm{m}}$ due to a lack of detailed observation data, rough comparisons to previous field observations suggested that the results are reasonable and meaningful, and have the potential to be applied in real algal blooms after further validation by more detailed observations. In addition, more considerations on the effect of self-shading and mucilage may be taken into the present model to improve its capability and quality in future studies.

Acknowledgements This work was financially supported by the Special Foundation (Class D) of the "Hundred Talents Program" of the Chinese Academy of Sciences (CAS), and by the National Natural Science Foundation of China (11202217).

\section{References}

Aksnes DL, Egge JK (1991) A theoretical model for nutrient uptake in phytoplankton. Mar Ecol Prog Ser 70:65-72. doi: 10.3354/meps070065

Bresciani M, Adamo M, De Carolis G, Matta E, Pasquariello G, Vaiciute D, Giardino C (2014) Monitoring blooms and surface accumulation of cyanobacteria in the Curonian Lagoon by combining MERIS and ASAR data. Remote Sens Environ 146:124-135. doi:10.1016/j.rse.2013.07.040

Chien YC, Wu SC, Chen WC, Chou CC (2013) Model simulation of diurnal vertical migration patterns of different-sized colonies of Microcystis employing a particle trajectory approach. Environ Eng Sci 30:179-186. doi:10.1089/ees.2012.0318

Costas E, Lopez-Rodas V, Toro FJ, Flores-Moya A (2008) The number of cells in colonies of the cyanobacterium Microcystis aeruginosa satisfies Benford's law. Aquat Bot 89:341-343. doi: 10.1016/j.aquabot.2008.03.011

Gao Y, Liu Q (2013) Dynamic criterion for the formation of surface water-blooms. Theor Appl Mech Lett 3:042003. doi: $10.1063 / 2.1304203$

Guven B, Howard A (2006) Modelling the growth and movement of cyanobacteria in river systems. Sci Total Environ 368:898-908. doi:10.1016/j.scitotenv.2006.03.035

Hajdu S, Hoglander H, Larsson U (2007) Phytoplankton vertical distributions and composition in Baltic Sea cyanobacterial blooms. Harmful Algae 6:189-205. doi: 10.1016/j.hal.2006.07.006

Hunter PD, Tyler AN, Willby NJ, Gilvear DJ (2008) The spatial dynamics of vertical migration by Microcystis aeruginosa in a eutrophic shallow lake: a case study using high spatial resolution time-series airborne remote sensing. Limnol Oceanogr 53:2391-2406. doi:10.4319/1o.2008.53.6.2391

Hutchinson GE (1967) A treatise on limnology. Introduction to lake biology and the limnoplankton, vol 2. Wiley, New York

Kong F, Fao G (2005) Hypothesis on cyanobacteria bloomforming mechanism in large shallow eutrophic lakes. Acta Ecol $\begin{array}{llll}\text { Sin/Shengtai Xuebao 25:589-595. } & \end{array}$ 10.3321/j.issn:1000-0933.2005.03.028

Kromkamp JC, Mur LR (1984) Buoyant density changes in the cyanobacterium Microcystis aeruginosa due to changes in the cellular carbohydrate content. FEMS Microbiol Lett 25:105-109. doi:10.1111/j.1574-6968.1984.tb01384.x

Kromkamp JC, Walsby AE (1990) A computer model of buoyancy and vertical migration in cyanobacteria. J Plankton Res 12:161-183. doi:10.1093/plankt/12.1.161

Liu L, Liu D, Johnson DM, Yi Z, Huang Y (2012) Effects of vertical mixing on phytoplankton blooms in Xiangxi Bay of Three Gorges Reservoir: implications for management. Water Res 46:2121-2130. doi:10.1016/j.watres.2012.01.029

Naselli-Flores L, Barone R (2003) Steady-state assemblages in a Mediterranean hypertrophic reservoir. The role of Microcystis ecomorphological variability in maintaining an apparent equilibrium. Hydrobiologia 502:133-143. doi: 10.1023/B:Hydr.0000004276.11436.40

Okada M, Aiba S (1986) Simulation of water-bloom in a eutrophic lake-IV Modeling the vertical migration in a population of Microcystis aeruginosa. Water Res 20:485-490. doi: 10.1016/0043-1354(86)90197-1

Oliver RL, Ganf GG (2002) Fresh water blooms. In: Whitton BA, Potts M (eds) The ecology of cyanobacteria-their diversity in time and space. Kluwer Academic, Dordrecht, pp 149-194

Rabouille S, Thebault JM, Salencon MJ (2003) Simulation of carbon reserve dynamics in Microcystis and its influence on vertical migration with Yoyo model. C R Biol 326:349-361. doi: 10.1016/S1631-0691(03)00123-9

Reynolds CS (2007) Variability in the provision and function of mucilage in phytoplankton: facultative responses to the environment. Hydrobiologia 578:37-45. doi: 10.1007/s10750-006-0431-6 
Reynolds CS, Walsby AE (1975) Water-blooms. Biol Rev Camb Philos Soc 50:437-481. doi:10.1111/j.1469-185X.1975.tb01060.x

Reynolds CS, Jaworski GHM, Cmiech HA, Leedale GF (1981) On the annual cycle of the blue-green alga Microcystis aeruginosa Kutz emend. Elenkin. Philos Trans R Soc Lond B Biol Sci 293:419-477. doi:10.1098/rstb.1981.0081

Scheffer M, Rinaldi S, Gragnani A, Mur LR, van Nes EH (1997) On the dominance of filamentous cyanobacteria in shallow, turbid lakes. Ecology 78:272-282. doi:10.2307/2265995

Shigesada N, Okubo A (1981) Analysis of the self-shading effect on algal vertical distribution in natural waters. J Math Biol 12:311-326. doi:10.1007/bf00276919

Shikata T, Matsunaga S, Nishide H, Sakamoto S, Onistuka G, Yamaguchi M (2015) Diurnal vertical migration rhythms and their photoresponse in four phytoflagellates causing harmful algal blooms. Limnol Oceanogr 60:1251-1264. doi: 10.1002/lno.10095

Visser P, Ibelings B, Van Der Veer B, Koedood J, Mur R (1996) Artificial mixing prevents nuisance blooms of the cyanobacterium Microcystis in Lake Nieuwe Meer, the Netherlands. Freshw Biol 36:435-450. doi:10.1046/j.1365-2427.1996.00093.x

Visser PM, Passarge J, Mur LR (1997) Modelling vertical migration of the cyanobacterium Microcystis. Hydrobiologia 349:99-109. doi:10.1023/A:1003001713560

Wallace BB, Bailey MC, Hamilton DP (2000) Simulation of vertical position of buoyancy regulating Microcystis aeruginosa in a shallow eutrophic lake. Aquat Sci 62:320-333. doi: 10.1007/PL00001338
Walsby AE, Reynolds CS (1980) Sinking and floating. In: Morris I (ed) The physiological ecology of phytoplankton. Blackwell Scientific Publications, Oxford, pp 371-412

Wang X, Qin B, Gao G, Paerl HW (2010) Nutrient enrichment and selective predation by zooplankton promote Microcystis (Cyanobacteria) bloom formation. J Plankton Res 32:457-470. doi:10.1093/plankt/fbp143

Wu XD, Kong FX (2009) Effects of light and wind speed on the vertical distribution of Microcystis aeruginosa colonies of different sizes during a summer bloom. Int Rev Hydrobiol 94:258-266. doi:10.1002/iroh.200811141

Wu XD, Kong FX (2010) Effect of excess light on colony size and photosynthetic quantum yield of Microcystis spp. during a summer bloom. J Freshw Ecol 25:507-516. doi: 10.1080/02705060.2010.9664399

Wu T, Qin B, Brookes JD, Shi K, Zhu G, Zhu M, Yan W, Wang Z (2015) The influence of changes in wind patterns on the areal extension of surface cyanobacterial blooms in a large shallow lake in China. Sci Total Environ 518-519:24-30. doi: 10.1016/j.scitotenv.2015.02.090

Yang Z, Kong FX, Shi XL, Cao HS (2006) Morphological response of Microcystis aeruginosa to grazing by different sorts of zooplankton. Hydrobiologia 563:225-230. doi: 10.1007/s10750-005-0008-9

Yu Q, Liu ZW, Chen YC, Zhu DJ (2015) Modelling daily variation in the vertical distribution of Microcystis. Zhongguo Huanjing Kexue/China Environ Sci 35:1840-1846. doi: $10.3969 /$ j.issn. 10006923.2015 .06 .029 